\title{
Correspondence
}

To the Editors

\section{Reintroduction of native centric education for children in COVID-19 lockdown}

Sri Lanka Journal of Child Health, 2020; 49(3): 308-309

http://dx.doi.org/10.4038/sljch.v49i3.9158

(Keywords; Covid-19 E-learning, native centric education, social distancing, schoolchildren, internet)

Covid-19 which originated in Wuhan, China in December 2019, evolved into a serious global emergency, leading to its declaration as a pandemic by the World Health Organization (WHO) ${ }^{1}$. Currently, Covid-19 has no cure. Increased mortality has been recorded worldwide due to the pandemic. To avoid further mortality, the WHO rolled out measures to control Covid-19. These measures include regular hand washing, the use of sanitizers, the use of facemasks and social distancing ${ }^{2}$.

To implement social distancing, governments have closed down churches, mosques, markets, airports and schools. Worldwide, schoolchildren have been at home for more than four months with only a few countries rendering skeleton services via the traditional medium of teaching and learning. This scenario is leaving millions of schoolchildren without access to proper education for a long period and this would be harmful to the educational development of the children. Currently, governments have suggested electronic learning (elearning) as an alternative method to the traditional method of teaching and learning.

This e-learning is the utilisation of digital devices for informal and non-formal education ${ }^{3}$. Digital learning affirms the social distancing strategy since Covid-19 can be transmitted mainly through close contact and respiratory droplets, with possible airborne transmission. Toritseju AA asserts that the COVID-19 pandemic is revolutionizing digital and on-line education globally but kids in rural and under-served communities are being left behind as they are not equipped to adapt or are able to transition to the new methods of learning ${ }^{4}$. Digitallearning comprises the use of e-mail, accessing course materials, teaching, and writing of examinations via the internet. It is an efficient transfer of knowledge anywhere and at any time, regardless of the subject matter ${ }^{5}$. The question is how many schoolchildren have access to e-learning facilities?

In Nigeria, a major challenge is the lack of electricity and low computer literacy among schoolchildren. More than 50 per cent of the rural populations have no access to electricity. Oye et al state that irregular and frequently interrupted power supply is a perennial problem affecting education and technological advancement ${ }^{5}$. Thus, schoolchildren in rural communities and urban centres would be left behind, as they may not be ready for digitallearning. We contend that e-learning is not sufficient to close the gap of teaching and learning due to lockdown of schools. We suggest Native Centric Education to complement e-learning. What is Native Centric Education?

With the current effect of globalization on cultures, it is imperative to reawaken the indigenous ways of life during this lockdown. Local centric education is the preparation of children for life to avoid cultural dislocations. It is character-based ethics and native centred philosophy, aimed at teaching and learning the indigenous ways of life. Who are the teachers of Native Centric Education? Native Centric Education is parenting, locally developed moral personhood, formed to bring up children by their parents, older and more experienced members of the tribe ${ }^{6}$. It deals with native centred epistemology, ethics, politics and aesthetics. The mode of transmission of knowledge is mostly oral rather than scriptural from generation to generation.

Local centric education is the traditional socialization and the humanistic foundations, goodwill, which help to unearth the uniqueness of the child in a moral community. Here children learn skills that would be appropriate for their socioeconomic and historical situation. Native centric education has no definite curriculum but the didactic level is the teaching process, which takes the form of stories, folklore, legends, riddles, and songs, while at the practical level, involves the learning of skills such as grazing, fishing, blacksmithing, cooking etc. ${ }^{6}$

\section{References}

1. Chinenyenwa O, Adeleye S. Bakarey B, Tauseef A. COVID-19 and Nigeria: Putting the realities in context. International Journal of Infectious Diseases 2020. Available from: 
https://www.ijidonline.com/article/S12019712(20)30281-2/pdf

2. World Health Organization. Coronavirus Disease (COVID-19) Situation Report 115. Available from: https://www.who.int/docs/defaultsource/coronaviruse/situationreports/20200514-covid-19-sitrep115.pdf?sfvrsn $=3$ fce $8 d 3 c \_6$

3. Sujit KB, Marguerite W, Paul B. Elearning, M-learning and D-learning: Conceptual definition and comparative analysis. E-Learning and Digital Media 2018; 15(4): 191-216.

https://doi.org/10.1177/204275301878518 0

4. Toritseju AA. COVID-19 has exposed the education divide In Nigeria. This is how we can close it. Available from:

https://www.weforum.org/agenda/2020/06 /education-nigeria-covid19-digital-divide/
5. Oye ND, Mazleena S, Iahad NA. Challenges of E-learning in Nigerian university education based on the experience of developed countries. International Journal of Managing Information Technology 2011; 3(2): https://doi.org/10.5121/ijmit.2011.3204

6. Darisoan J. What Is African indigenous education? Philosophical basis of African indigenous education. Strengths and limitations of this education. How relevant is it to modern education today 2012. Available from:

https://darisoanj.wordpress.com/2012/02/0 8/what-is-african-indigenous-educationphilosophical-bases-of-africanindigenous-education-strengths-andlimitations-of-this-education-and-relevantis-it-to-the-modern-education-today

\section{Osebor Ikechukwu Monday}

Delta State Polytechnic ogwashi-uku. pmb 1030 nigeri, Nigeria

Correspondence: osebordarry@yahoo.com

orcid.org/ 0000-0002-2642-662X 